\title{
SOCIOLOGY IN UKRAINE: INSTITUTIONAL STATUS AND RESEARCH AGENDA
}

\author{
Vil Bakirov \\ Doctor of Sciences (Sociology), Full Professor, Academician of the National Academy of Sciences of \\ Ukraine, Corresponding Member of the Academy Pedagogical Sciences of Ukraine, \\ President of the V. N. Karazin Kharkiv National University, President of Sociological association of \\ Ukraine, 4 Svobody Sq., Kharkiv 61022, Ukraine, \\ rektor@karazin.ua, ORCID ID https://orcid.org/0000-0001-5110-3403
}

\begin{abstract}
Liudmyla Sokurianska
Doctor of Sciences (Sociology), Full Professor, Head of The Department of Sociology V. N. Karazin Kharkiv National University, Vice President of Sociological association of Ukraine, 4 Svobody Sq., Kharkiv 61022, Ukraine, sokuryanska@karazin.ua, ORCID ID https://orcid.org/0000-0002-4097-952X
\end{abstract}

The article provides a comparative review of the history, current status and areas of scientific activity of the Sociological Association of Ukraine (SAU), its creative ties with the European and world sociological community, in particular, joint research with Polish scientists. It emphasizes that most of the Ukrainian sociologists SAU members work in universities, the Institute of Sociology of the National Academy of Sciences of Ukraine, and public opinion research centers. Numerous sociological (theoretical and empirical) studies on various issues of vital activity of modern Ukrainian society are carried out by their efforts. It is noted that in addition to studying the issues of social transformation in its political, economic, legal, social and cultural aspects, that have become traditional for Ukrainian sociology, in recent years Ukrainian sociologists have turned to the analysis of such problems as external and internal migration (the problem of internally displaced persons); military conflict in the east of Ukraine and the volunteer movement; social inequality, including in its new manifestations, including those caused by the digitalization of public life. It is emphasized that today the most pressing issue of sociological reflection is the changes that occur in Ukraine after the last presidential election. Attention is focused on the fact that the victory of the political rookie in these elections was due to the huge social disappointments of the Ukrainians, since their expectations provoked by the Revolution of Dignity were not fulfilled. The first and most important disappointment, according to sociological studies, is the fact that peace has not reigned in the country. Second, the living standards of Ukrainian citizens have not improved. Third, the fight against corruption did not bring significant results. Fourth, social inequality deepened: the rich became richer, and the poor became poorer. The fifth disappointment is the inefficiency of the declared reforms: judicial, medical, educational, customs, electoral, etc. It is emphasized that the effectiveness of the new government depends, among other things, on its consideration of such features of the mass consciousness of the Ukrainian population as a critical level of distrust of all institutions of power; value and ideological ambivalence and uncertainty. The conclusions are formulated about the unlikeliness of return of Ukraine to the orbit of Russian political and economic influence, as well as the victory of radical nationalist ideology in our country.

Keywords: Sociological Association of Ukraine, social transformation, social inequality, war conflict, occupied territories and their reintegration, presidential election, social disappointments bifurcation point. 


\section{Соціологія в Україні: інституціональний статус та актуальні дослідження}

Віль Бакіров

доктор соціологічних наук, академік НАН України, професор кафедри прикладної соціології та соціальних комунікацій, ректор Харківського національного університету імені В. Н. Каразіна, Президент Соціологічної асоціації України, майдан Свободи, 4, Харків 61022, Україна, rektor@karazin.ua, ORCID ID https://orcid.org/0000-0001-5110-3403

Людмила Сокурянська докторка соціологічних наук, професорка, завідувачка кафедри соціології Харківського національного університету імені В. Н. Каразіна, віцепрезидетн Соціологічної асоціації України, майдан Свободи, 4, Харків 61022, Україна, sokuryanska@karazin.ua, ORCID ID https://orcid.org/0000-0002-4097-952X

У публікації здійснено порівняльний огляд історії, сучасного стану та напрямків наукової діяльності соціологічної асоціації України (САУ), її творчих зв'язків з європейською та світовою соціологічною спільнотою, зокрема спільних досліджень із науковцями Польщі. Підкреслено, що переважна частина українських соціологів-членів САУ працюють в університетах, Інституті соціології Національної академії наук України та центрах дослідження громадської думки. Їхніми зусиллями здійснюються численні соціологічні (теоретичні та емпіричні) дослідження з різноманітних питань життєдіяльності сучасного українського суспільства. Зазначено, що окрім вивчення традиційних для вітчизняної соціології питань соціальної трансформації у її політичних, економічних, правових, соціальних та культурних аспектах, в останні роки українські соціологи звертаються до аналізу таких проблем, як зовнішня та внутрішня міграція (проблема внутрішньо переміщених осіб); військовий конфлікт на Сході України та пов'язаний з ним волонтерський рух; соціальна нерівність, у тому числі в її нових проявах, зумовлених дигіталізацією суспільного життя тощо. Підкреслено, що сьогодні найактуальнішим питанням соціологічної рефлексії є ті зміни, що відбуваються в Україні після останніх президентських виборів. Акцентовано увагу на тому, що перемога політичного новачка на цих виборах зумовлена величезними соціальним розчаруваннями українців, оскільки їхні очікування, спровоковані Революцією Гідності, не були здійснені. Перше і найважливіше розчарування, як свідчать соціологічні дослідження, пов'язане з тим, що в країні так і не запанував мир. Друге - життєві стандарти українських громадян не покращились. Третє - боротьба з корупцією не принесла суттєвих результатів. Четверте - соціальна нерівність поглибилась: багаті стали ще більш багатими, а бідні - біднішими. П'яте розчарування - неефективність задекларованих реформ: судової, медичної, освітньої, митної, виборчої та ін. Підкреслено, що ефективність діяльності нової влади залежить, у тому числі, від врахування нею таких особливостей масової свідомості українського населення, як критичний рівень недовіри до всіх інститутів влади; ціннісна та ідеологічна амбівалентність та невизначеність. Сформульовано висновки щодо малої ймовірності повернення України на орбіту російського політичного та економічного впливу, а також перемоги радикальної націоналістичної ідеології на теренах нашої країни.

Ключові слова: Соціологічна асоціація України, соціальна трансформація, соціальна нерівність, військові конфлікти, окуповані території та їхня реінтеграція, президентські вибори, точка біфуркації соціальних розчарувань.

В статье осуществлен сравнительный обзор истории, современного состояния и направлений научной деятельности социологической ассоциации Украины (САУ), ее творческих связей с европейским и мировым социологическим сообществом, в частности совместных исследований с учеными Польши. Подчеркнуто, что большая часть украинских социологов-членов САУ работают в университетах, Институте социологии Национальной академии наук Украины и центрах исследования общественного мнения. Их усилиями осуществляются многочисленные социологические (теоретические и эмпирические) исследования по различным вопросам жизнедеятельности современного украинского общества. Отмечено, что кроме изучения вопросов социальной трансформации, ставших традиционными для отечественной социологии в ее политических, экономических, правовых, социальных и культурных аспектах, в последние годы украинские социологи обращаются к анализу таких проблем, как 
внешняя и внутренняя миграция (проблема внутренне перемещенных лиц); военный конфликт на Востоке Украины и связанное с ним волонтерское движение; социальное неравенство, в том числе в его новых проявлениях, в том числе обусловленныхдигитализацией общественной жизни. Подчеркнуто, что сегодня самым актуальным вопросом социологической рефлексии являются изменения, которые происходят в Украине после последних президентских выборов. Акцентировано внимание на том, что победа политического новичка на этих выборах обусловлена огромными социальным разочарованиями украинцев, поскольку их ожидания, спровоцированные Революцией Достоинства, не были осуществлены. Первое и самое важное разочарование, как свидетельствуют социологические исследования, связано с тем, что в стране так и не воцарился мир. Второе - жизненные стандарты украинских граждан не улучшились. Третье - борьба с коррупцией не принесла существенных результатов. Четвертое - социальное неравенство углубилось: богатые стали еще богаче, а бедные - беднее. Пятое разочарование - неэффективность задекларированных реформ: судебной, медицинской, образовательной, таможенной, избирательной и др. Подчеркнуто, что эффективность деятельности новой власти зависит, в том числе, от учета ею таких особенностей массового сознания украинского населения, как критический уровень недоверия ко всем институтам власти; ценностная и идеологическая амбивалентность и неопределенность. Сформулированы выводы о маловероятности возвращения Украины в орбиту российского политического и экономического влияния, а также победы радикальной националистической идеологии в нашей стране.

Ключевые слова: Социологическая ассоциация Украины, социальная трансформация, социальные неравенства, военные конфликты, оккупированные территории и их реинтеграция, президентские выборы, точка бифуркации социальных разочарований.

The majority of Ukrainian sociologists are united in the Sociological Association of Ukraine, separated from Soviet Sociological Association in 1990. In its current status, SAU was constituted at the founding convention in 1990 , and since 1993 it is a member of the International Sociological Association. Today SAU consists of 17 regional branches, it has more than 1300 individual and 25 collective members.

From the point of view of internal structure sociology in Ukraine mostly represented now in universities, Institute of Sociology of National Academy of Sciences of Ukraine and several public opinion research centers (mostly private). About 30 universities in Ukraine provide sociological education as a speciality. Every year about 500 new bachelors and masters of Sociology graduate form Ukrainian universities, every year we have about 20 new $\mathrm{PhD}$ in Sociology, and about 5 Doctors of Science in Sociology.

Ukrainian sociology is in development and nowadays we have sociological research centersin Kharkiv, Kyiv, Odesa and Lviv, some other major cities. Sociological Association of Ukraine based in Kharkiv, where it held three Congresses: the I Congress "Sociology in the Situation of Social Uncertainties" (2019), II Congress "Sociology and Society: Collaboration in a Crisis" (2013) and in III
Congress "New Inequalities - New Conflicts: Ways to Overcome" (2017). We had a great discussion on many sociological problems of modern Ukraine, our neighbors and future of the world. More than 2500 sociologist participated in these three Congresses.

One of the most respected sociological institutions in Ukraine is Institute of Sociology of National Academy of Sciences of Ukraine. It is a serious academic research center that provides not only wide range of theoretical researches and publications, but conduct annual sociological monitoring "Ukrainian society: monitoring of social change", where we can find unique data in dynamics and analysis of social changes of Ukrainian society since 1992.

There are many Public opinion research Centers in Ukraine that conduct highly qualified sociological researches: Kantar TNS Ukraine, Sociological Group «Rating», Kyiv International Institute of Sociology, Razumkov Center and The Ilko Kucheriv Democratic Initiatives Foundation (Dif), GfK Ukraine, The East-Ukrainian Foundation for Social Research, Oleksandr Yaremenko Ukrainian Institute for Social Research and others. Sociological Association of Ukraine made special accreditation procedure to separate real and reliable sociological organization from fake ones. 
But all these organizational and activity achievements were not accompanied by active sociological understanding of their own sociological identity, orientation and efficiency.

The purpose of this publication is to highlight the main areas of reflection of contemporary Ukrainian sociology.

Summarizing Congresses' discussions, one can state that there are several important topics in the focus of Ukrainian sociologists' attention. Some of them are traditional to our sociological schools, and some of them are new and reflect new social phenomena.

Perhaps, the most discussed problems in modern Ukrainian sociology are issues of social structures and social inequality. The overcoming of the conflict between equality and inequality is possible on the way of reconstructive development, which consists in rebuilding the supporting structures of the economy and radically changing its structure on the basis of the predominance of qualitative changes over quantitative, which causes the change of the criterion of development and makes the development possible both under economic growth and under zero (and even negative) economic growth rates. The peculiarities of the Ukrainian economy, related to the inversion type of market transformation, make solving the basic problems of people's livelihood the top priority.

Very interesting issue of modern Ukrainian sociology are the "new inequalities". They appear as an unequal access of people to such social resources, as good education, employment, fair payments, pensions, medical care, government, fair political participation, access to Internet resources, cultural resources, language competences etc.

Classes and social institutions, middle class, informal employment, gender, feminism that is also interesting cases of Ukrainian sociology of social differentiation in last years.

Soviet and post-soviet transformations are also in the focus of Ukrainian sociology. This is very complex problem that tries to clarify "starting positions" of modern Ukrainian society, by studying soviet society and its influence on our nowadays. Problems of working class in Soviet Union and modern Ukraine, police nature of soviet passport system migration in soviet and post-soviet period, social solidarity in both periods that's only few examples from publications in 2018 on issue of post-soviet transformations, that influence on Ukrainian society till today. Reflection on Marxism and neo-Marxism theories also are a part of sociological discussions in modern Ukraine.

The sociology of education attracts the attention of many Ukrainian researchers. Commercialization and digitalization of higher end basic education, competition in global educational markets, MOOCs, mission and role of modern universities, and there future got the attention of Ukrainian sociologists.

Issues of internal migration were not in the focus of Ukrainian sociology until 2014. Since the start of military conflict, we had to study a new social phenomenon for Ukraine - internally displaced persons. These people, who left their homes due to the military actions or social and political conflict with their neighbors or other different reasons, were terra incognita not only for our government but for social sciences too. We studied different aspects not only of this phenomenon, but the ways to help them to fit new conditions. Huge attention was given to quite new social phenomenon in Ukraine - namely volunteering and military cooperation. Collected data, personal experience, transformation of polling methods (to CATI and online-interviews), work with UN, UNDP, USAID and own methodologies, makes Ukrainian experience unique for scientific research in this area.

Some time ago, we started a discussion about place and of role of sociology and sociologist in time and place of war conflict.

Ukrainian sociologists participate in many international projects. Particularly active is the interaction of Ukrainian sociologists with Polish colleges. There is an important participation of both Polish and Ukrainian research teams in major international projects, such as: European Social Survey (in Ukraine, National Coordinator A. Horbachyk, 2004-2012), International Social Survey Program (in Ukraine, National Coordinator O. Ivashchenko, 2007, 2008), European Value Survey(Ukrainian coordinatorO. Balakireva). It gives an opportunity to compare data on social processes and problems in our countries in a broader European and global context. 
There is an important participation of both Polish and Ukrainian research teams in major international projects, such as: European Social Survey (in Ukraine, National Coordinator A. Horbachyk, 20042012), International Social Survey Program (in Ukraine, National Coordinator O. Ivashchenko, 2007, 2008), European Value Survey (Ukrainian coordinator O.Balakireva). - It is an opportunity to compare data on social processes and problems in our countries in a broader European or global context.

We can mention such examples of Ukrainian-Polish scientific cooperation as research projects "Students on the Borderlands of Central and Eastern Europe: Identities, Values, Life Plans." (projects leaders: from Poland - Professor M. Zelinska (University of Green Gura), from Ukraine - professor L. Sokurianska (V. N. Karazin KhNU); "Teenage Youth on the Borderlands of Central and Eastern Europe" (project leaders: from Poland - Professor P. Długasz (University of Rzeszów),from Ukraine Professor L. Sokurianska (V. N. Karazin KhNU), Professor S. Shchudlo (I. Franko Drohobych State Pedagogical University).

Ukrainian sociologist often use polish scientific publications to present results of their work [1-5]. This is just a few examples of cooperation between our sociological communities.

To consolidate all modern trends and achievements of Ukrainian sociology, a collective monograph "Ukrainian Sociology in the 21st Century: Theory, Methods, Research Results" was published last year [6]. It included texts of leading scholars. In the book you can find all main issues that Ukrainian sociology focuses on.

In section "History and Theory of Sociology" we discussed wide specter of sociological problems: from "presentday sociology: tendencies and prospects of development" to "genealogy of the ideology of development in the post-leninist Ukraine"; from "value field of a person as the manifestation of the individual consciousness ambivalence" to "cultural security phenomenon: theoretical framework for investigation". This section would be interesting for scientist that wants to know universal patterns and ideas that could be used not only in Ukrainian society, but in common.
In second section of "Methodology and Methods of Sociological Research", we gathered most interesting and fundamental works on methods of modern sociology, such as "Up-to-date view on the crisis in survey methods and ways to overcome it", "Comparative analysis of mass attitudes in different types of European welfare regimes". Interesting and polemical works "Sociology in times of crisis and war: problem of the methodological efficiency" and "Testing the Cultural Quotient Scale (CQS): Ukrainian Audience" could be useful for sociologist because of unique data for these articles.

The third section of this fundamental work, called "Ukrainian Society: The Problems of Transformation" dedicated to the specific issues of modern Ukrainian society. However, it would be interesting because of topics we discuss there: internal migration and collective actions of overcoming them (in terms of the military conflict in the east of Ukraine, 2014-2017), Ukrainian universities in European educational and scientific space, ethnic groups and minorities in Ukraine and many others.

The integral task of Ukrainian sociology today is to understand the situation in which Ukrainian society found itself after the presidential and parliamentary elections of 2019 and the radical change of political elites associated with them.

All the many problems of interest to Ukrainian sociologists, one way or another, stems from the state in which society has been after almost thirty years of post-Soviet transit from administrative-type economy and one-party totalitarian political system to market economy and political pluralism. Today the country stands at the bifurcation point, the point of critical instability in its development where the system reconstructs itself selecting one of the several possible routes of its future unfolding.

First of all, it should be noted that Ukraine is very diverse and due to this heterogeneity it is considerably fragmented in geographical, ethnic, cultural, religious and other senses. Ukraine's east is noticeably different from its west, south from center. Regions vary in culture, language, mentality, political sympathies, etc.

Economic, social, cultural differences were not completely got over after joining western lands following World War II. 
Obviously, some gradual convergence of Ukraine's different regions took place and differences were becoming less conspicuous as compared to the first half of the $20^{\text {th }}$ century.

But these differences are still preserved today and they can be traced in the peculiarities of mentality, language, religion, as well as in historical memory, for instance such issue as who can be considered a national hero. Politicians appeal to these differences and that is why during elections different regions of Ukraine vote differently and demonstrate different political preferences.

For instance, at presidential elections west-Ukrainian voters supported proEuropean and nationally-oriented candidates, while voters from Eastern and Southern regions demonstrated their preference of proRussian candidates.

But presidential election in May of 2014 demonstrated relative electoral unanimity. The election was held against the background of Crimea's annexation and emerging hostilities in Donbas region with Russian Federation's direct involvement.

In the face of aggression and military threat, Petro Poroshenko, who promised to put an end to the conflict in two weeks and didn't exploit ethnic and cultural differences among the regions, received $56 \%$ of votes in the first round of election in almost all Ukrainian regions. The country realized that in conditions of a high probability of a fullscale military intervention of the eastern neighbour, legitimate president and restored structures of state power were absolutely necessary.

What happened during the period of five years that led the triumpher of the 2014 election to a landslide defeat to a political novice and complete dilettante?

What made people of all ages forget about their regional, mental, ethnic, cultural and other differences and once again vote similarly in majority of Ukrainian regions?

Laying no claim on absolutely correct analysis and corresponding judgments, we'll let ourselves express some considerations on the basis of sociological research.

The 2014 election was held immediately after Maidan, mass street protests of hundreds and thousands of people, during which more than a hundred people were shot dead in the governmental district of downtown Kyiv and the then president Victor Yanukovich fled to Russia.
This protest was provoked by a feeling of deep indignation about authorities who violated human rights and freedoms, behaved in a rude and shameless manner. Those events were later called the revolution of dignity. Political turbulence that followed and general weakness of the new power allowed Russian Federation to occupy Crimea and part of Donbas region against all norms of international law, particularly Helsinki accord and Budapest Memorandum of 1992 that guaranteed to Ukraine security and territorial integrity in exchange of refusal from nuclear weapons.

In the spring of 2014 Ukrainians had several important expectations that were instigated by the Revolution of Dignity and war. Unfortunately, none of them came true. Moreover, with time these expectations transformed into five huge social disappointments which fact is supported by sociological research.

Disappointment 1. War conflict was not stopped. According to all sociological surveys, peace is Ukrainians' number one priority.

People are tired of war but the peace they were promised never happened. The war has been going on for 5 years and it has become a bleeding wound that led to the death of more than 13 thousand people. We have a memorial plaque with the names of five young men, University's graduates, who were killed in this conflict. Cemeteries of Ukrainian cities and villages have alleys with thousands of graves of the soldiers who lost their lives in the fights for Donbass. More than a million and a half of locals fled their homes and turned into internally displaced persons, in fact refugees still living in unacceptable conditions. Economic damage is so huge it can hardly be determined.

Disappointment 2. Living standards haven't improved. People understood that the war required some sacrifice and were ready to grin and bear it. But now, five years later they see no real perspective for any improvement (though, speaking objectively, the situation has become a little better within last two years). They are dissatisfied with low income, high prices and the lack of proper conditions for doing business. According to some estimates, about 4 million Ukrainians went abroad in search of better jobs. They are forced to go to Poland, Russia, Spain, Portugal and other countries to make enough money for their families. 
Disappointment 3. After the Revolution of Dignity, despite its big name, the society didn't feel more dignified. Large-scale corruption involving a lot of representatives of ruling elite is still plaguing the country. Despite the creation of a string of special agencies aimed at fighting corruption (National Anticorruption Bureau of Ukraine, Special Anticorruption Prosecutor's Office, National Agency on Fighting Corruption, State Bureau of Investigation, Anticorruption Court) no tangible results have been obtained which adds frustration to citizens.

Disappointment 4. People in Maidan also stood for social justice, against privileged position of political elites accustomed to receive political dividends from usurping state power. People fought against outrageous social and property inequality. And yet, today the rich are even richer and the poor - poorer. Ukraine remains the country with a very high level of inequality, with demonstratively luxurious level of consumption among the representatives of the wealthy layers.

Disappointment 5. Inconsistency and inefficiency of proclaimed reforms. The government declared about some serious reforms directed at transformation of the major social institutions - court reform, law-enforcement reform, medical reform, education reform, taxation reform, electoral reform, etc. Basically none of them yielded any decent results.

It would be unfair to say that nothing has been done or nothing is being done. But the reforms have been implemented too slowly; people poorly understand their meaning and aim, see no practical results and consequently do not support them. We have conducted 16 focus group interviews with faculty and $16-$ with students in different regions of Ukraine in order to evaluate their attitude towards the reform of higher education. As it turned out, practically all the subjects of these focus group interviews did not understand the contents of this reform and, thus, could not accept it.

All these frustrations resulted in mass protest voting at the presidential election. People voted not so much for a new candidate as against the old one who in their eyes embodied the power that didn't meet their expectations and disappointed them.

The voters faced the choice: whether to

prolong post-Soviet neo-patrimonial status quo threatening to never end, or to make a step towards new risks, uncertainty and unpredictability but at the same time with a good chance for changes, for radical reformation of power. And all this despite the military confrontation with Russia.

Those who came to the presidential elections opted for the latter.

Let us take a look at the spirits in which Ukrainian citizens made this leap into undetermined future.

First of all, it's a critical level of distrust towards all the institutions of power. New power will have to renew the trust of people, look for new and more efficient forms and communication channels. It is a very difficult task for Ukraine where people are used to receiving major portion of all information from TV. For the beginning of 2019, central TV channels (the biggest ones with national audience) remained the leading source of information for $74 \%$ of Ukrainians aged 18 and older.

The problem is that all the central TV channels (with exception of recently created Public Television whose audience is still very modest) are in private hands. They belong to different oligarchs - superrich people who control parliament, executive power, local governments, and media resources. In Ukraine, unlike in Russia, state does not control TV information and its consumption.

Recently, there has been a tendency towards decline in the popularity of all Ukrainian TV channels. $27,5 \%$ of adult Ukrainians use national Internet-media as the main source of information (though only $13,9 \%$ trust them). Besides, the most popular Internet-media, according to the results of mediametric research, are those controlled by the same oligarchs, or politicians, or are anonymously owned. Among 50 most popular Internet resources there are quite a lot of openly manipulative and pro-Russian ones.

For $23,5 \%$ of Ukrainians, social networks serve as the main source of information, though only $12.4 \%$ of respondents trust them. Vast majority of those who give preference to social networks as a source of information, use Facebook. With total population of 42-43 million, more than 12 million of Ukrainians are registered Facebook users. The main age of Facebook audience is 25-34 years. Facebook turned into an important media platform for social 
discussions that plays an important role in the life of the country.

Ukrainian segment of Facebook is the place with the highest level of concentration of social activists, public leaders, influencers but also political bots. It's not accidental that Ukrainian politicians have been actively employing this social network for their own advancement. Current presidential and forthcoming parliamentary campaigns are not exceptions.

By the end of 2018, the number of Ukrainian Instagram users had reached 7.3 million. It's most popular among young people between 18 and 24. It's interesting that Presidential candidate Volodymyr Zelenskii in addition to entertainment and information TV actively used Instagram and YouTube (but not Facebook) for his popularization.

The second trait of Ukrainian mass consciousness is its ambivalence and indeterminacy in questions of values and ideologies. There is no unity as to the priority model of social and economic development. One part of the society is moreor-less oriented towards national-democratic ideology. Considerable part of population about $20 \%$ - characterizes themselves as proponents of different versions of leftistconservative views. Liberals and nationalists have $2-3$ percent each. But more than half of the respondents cannot refer themselves to any particular ideological trend.

This fact creates nutritious ground for populism with prevalence of emotional over rational, hinders conscious mobilization of the society around particular strategic programs of social and economic modernization without which sustained and dynamic economic growth is simply impossible.

Another huge problem is geopolitical ambivalence of mass consciousness. For a long period of time the number of the supporters of "eastern" (pro-Russian) and "western" (proEuropean) vectors was approximately equal. Nowadays, public interest has somewhat shifted towards further approaching NATO and EU.

But according to the sociological surveys, there is no confident prevalence of a certain geopolitical vector and sociologists fear that in case of a possible referendum on this issue the society can simply be split and fragmented.

So, what can be said at the end of this sketchy characterization of Ukraine's current situation? What possible conclusions can be drawn as to the scenarios of its future development?

Conclusion 1. The revenge of proRussian forces and Ukraine's return to the orbit of Russian political and economic influence are very unlikely, if possible at all. A new generation of people has emerged with new, modern, post-materialistic (as they say) views, who reject the social model demonstrated by Russia, who could see and estimate western standards of social organization with their own eyes.

Conclusion 2. It's also very unlikely that the Ukrainian society will lock itself in the shell of traditional nationalism, whose proponents are few and concentrated in several western regions of Ukraine.

Speedy integration of new and new segments of Ukrainian society into the realm of Internet, popular involvement with new media, mass character of higher education and general growth of the population's educational level (despite some serious complaints in the address of the system of higher education) give hope for a more and more active formation of a new political culture, for a more mature civil society and, finally, a radical renewal of political elites and reformation of the whole system of power.

\section{Bibliography}

1. Sokurianska L. Educational reform in Ukraine: the risks of irresponsibility actualization Stugia nad wiedza. Wiedza a instytucjonalizacja nieodpowiedzialności / Red. Mariusz Zemło, Arkadiusz Jabłoński, Jan Szymczyk. Lublin: Ratol / uniwers Jana Pawla II, 2014. Tom. VI. C. 379-388;

2. Sokurianska L., Schudlo S. Tożsamość obywatelska oraz plany emigracyjne studenckiej młodzieży wschodniego I zachodniego przygranicza Ukrainy. Pogranicza i centra współczesnej Europy. Różnorodność praktyk i teorii / red. nauk. Dorota Szaban, Justyna nyćkowiak, Tomasz Kołodziej. Zielona Góra: Lubuskie Towarzystwo naukowe, 2015
(Transgraniczność w perspektywie socjologicznej. Seria Monograficzna; Tom IX, część 2). pp. 293-309

3. Sokurianska L., Agamiryan L. Practices of leisure of teenage youth of Central and Eastern europe's borderlands as a space of their value preferences realization. Youth in Central and Eastern Europe. Sociological Studies, 2016. №2(6). pp. 51-65. URL: http://www.youthjournal.eu/Youth\%20Yournal\%206-2016-3.pdf;

4. Kalashnikova A. A. Specialist Media as the Art Field and the Art Market Evolution Reflector. Media i społeczeństwo Vol. 5 / 2015. Bielsko-Biała: Akademia Techniczno-Humanistyczna. 
Pp. 86-94. (Index Copernicus) URL : http://www.mediaispoleczenstwo.ath.bielsko.pl/art/05/05 kalashnikova.pdf

5. Khyzhniak O. Strategic planning of university (school) development as an element ofeducational policy (case study experience). Youth in Centraland Eastern Europe. Sociological
Studies. 1 (5). 2016. P. 30-50. URL: http://www.youthjournal. eu/Youth\%20Yournal\%205(1)-2016.pdf (Index Copernicus).

6. "Ukrainian Sociology in the 21st Century: Theory, Methods, Research Results"/edited by Vil Bakirov, Evhen Golovakha. Kharkiv: V. N. Karazin Kharkiv National University, 2018. 560 p.

\section{References}

1. Sokurianska, L. (2014) Educational reform in Ukraine: the risks of irresponsibility actualization. Studies on knowledge. Knowledge and institutionalization of irresponsibility. In Mariusz Zemło, Arkadiusz Jabłoński and Jan Szymczyk (eds.) Lublin: Ratol University of John Paul II. Tom. VI, pp. 379-388

2. Sokurianska, L., and Schudlo, S. (2015) Civil identity and emigrational attitudes of student youth of east and west borderland of Ukraine. Borderlands and Centers of modern Europe. A variety of practices and theories. In Dorota Szaban, Justyna nyćkowiak and Tomasz Kołodziej (science eds.) Zielona Góra: Lubuskie Scientific Society, (Transborderness in the sociological perspective. Monographic Series; Volume IX, Part 2), pp. 293-309

3. Sokurianska, L., Agamiryan, L. (2016) Practices of leisure of teenage youth of Central and Eastern europe's borderlands as a space of their value preferences realization. Youth in Central and Eastern Europe. Sociological Studies
№2(6), pp. 51-65. Available at: http://www.youthjournal.eu/ Youth\%20Yournal\%206-2016-3.pdf

4. Kalashnikova, A. A. (2015) Specialist Media as the Art Field and the Art Market Evolution Reflector. Media i społeczeństwo. Vol. 5, pp. 86-94. Available at: http://www.mediaispoleczenstwo.ath.bielsko.pl/art/05/05_kalashnikova.pdf;

5. Khyzhniak, O. (2016) Strategic planning of university (school) development as an element ofeducational policy (case study experience). Youth in Centraland Eastern Europe. Sociological Studies. 1 (5), pp. 30-50. Available at: http://www. youthjournal.eu/Youth\%20Yournal\%205(1)-2016.pdf (Index Copernicus).

6. Vil Bakirov and Evhen Golovakha (eds.) (2018) Ukrainian Sociology in the 21st Century: Theory, Methods, Research Results. Kharkiv: V. N. Karazin Kharkiv National University 